\title{
221 デュアルフラッシュX線装置
}

$\begin{array}{lrr}\text { 岩手医科大学教養部物理学教室 } & \text { 佐藤英一 } & \text { 、寒河江康朗、大泉貞治 } \\ \text { 東北大学流体科学研究所 } & \text { 小島英則、高山和喜 } \\ \text { 岩手医科大学付属病院中央放射線部 } & \text { 玉川芳春 } \\ \text { 岩手医科大学医学部放射線医学講座 } & \text { 柳沢融 } \\ \text { 東日本機電開発 } & \text { 藤原秋浩、水户谷完爾 }\end{array}$

\section{Dual Flash X-Ray Generator}

\author{
Eiichi SATO*, Michiaki SAGAE*, Teiji OIZUMI*, Hidenori OJMA**, \\ Kazuyoshi TAKAYAMA**, Yoshiharu TAMAKAWA***, Toru YANAGISAWA****, \\ Akihiro FUJIWARA ***** and Kanji MITOYA*****
}

The constructions and the fundamental studies of a high-intensity flash $\mathrm{x}$-ray generator having two flash $\mathrm{x}$-ray tubes are described. This generator consisted of the following essential components: a high-voltage power supply, a high-voltage pulser, a thyratron pulser, a turbo molecular pump, and two flash $\mathrm{x}$-ray tubes. The high-voltage pulser employed a polarity-inversion-type transmission line with two high-voltage outputs. The combined ceramic condenser of about $5 \mathrm{nF}$ was charged from -60 to $-80 \mathrm{kV}$ by a power supply, and the electric charges in the condenser were discharged to two x-ray tubes through $5.0 \mathrm{~m}$ coaxial cables after closing a gap switch by the thyratron pulser. Using a tube, the pulse widths were less than $200 \mathrm{~ns}$, and the $\mathrm{x}$-ray intensity was less than $5 \mu \mathrm{C} / \mathrm{kg}$ at $0.5 \mathrm{~m}$ per pulse. The maximum (peak) values of the tube voltage and the current were about $110 \mathrm{kV}$ and $3 \mathrm{kA}$, respectively. When two tubes were employed, comparatively stable two $\mathrm{x}$-ray outputs were obtained simultaneously.

\section{1.はじめに}

フラッシュX 線装置 ${ }^{1-4)}$ は高速度で運動する不透明物体の可視化には抜群の 威力を発揮するが、撮影目的に応じた装置の選択が必要となる。近年、CRシス テムが登場し、低線量撮影もある程度可能となったが、鮮明な画像を得るには大 線量のX線が必要となる。次に画像コントラストを高めるためには被写体に合わ せたX線スペクトルの調整が大切である。

一般的なフラッシュX線装置は、高電圧パルサと冷陰極二極管を組合せること により構成される。 ${ }^{5}$ 簡単なデュアルフラッシュX線装置ではパルサに 2 本の管 が接続される。したがって 2 本の管を同時にしかも安定に放電させることが必要 となる。

本研究では 2 本の管を持つデュアルソフトフラッシュX線装置を試作し、フォ トンエネルギーが同等あるいは異なるX線の 2 方向同時照射を試みた。

*Department of Physics, Iwate Medical University, **Shock Wave Research Center, Institute of Fluid Science, Tohoku University, ${ }^{* * *}$ Center for Radiological Science, Iwate Medical University, ****Department of Radiology, Iwate Medical University, Japan Mechaelectric Inc. 


\section{2. 装置}

Fig. 1 には装置の主放電回路とブロック図が示してある。装置は高電圧充電装 置、極性反転式高電圧パルサ、サイラトロンパルサ（トリガ装置）、ターボ分子 ポンプおよび 2 本のフラッシュX線管等より成る。パルサ内の高電圧コンデンサ を60〜80 kVに負充電し、サイラトロンパルサにてギャップスイッチを閉じると、 蓄積された電荷が 2 本のフラッシュX線管に同時に放出される。X線管は夕ーボ 分子ポンプにより連続排気される。実験に用いた管はタングステン製の棒状陽極、 フェライト製の環状陰極、およびアクリル管体等より成る。フェライト陰極を使 用した際には安定した真空放電が得易い。

\section{3. 特性}

充電電圧 (絶対値) の増加とともにパルサ出力電圧の尖頭值も増加する。放電 回路には電圧を高めるために5.0 mの同軸ケーブルを採用したので、 1 本と 2 本 のケーブルを用いた場合の出力電圧の尖頭值はそれぞれ充電電圧の約 $-1.5 と-1.3$ 倍である。1本のケーブル（管）を用いた場合の管電圧は Fig. 2 に示す通りであ る。管電圧の尖頭値は充電電圧および陽陰極間距離を増すことにより増加する。 2 本のケーブル（管）を用いた場合には、陽陰極間の相対的位置関係を一定に保 つことにより、同フォトンエネルギーX線の照射が可能である[Fig. 3 (a) 参照]。 言い替えれば位置関係を変えることにより、異なるエネルギーの同時照射ができ る[Fig. 3 (b) 参照]。

\section{4. ラジオグラフィー}

デュアルフラッシュX 線装置は長さを持つ高速度現象の撮影に有用である

(Fig. 4 参照)。Fig. 5 は振動する長スプリングの撮影例である。充電電圧は 80 $\mathrm{kV}$ で、管電圧は Fig. 3 (a) に示す条件である。同フォトンエネルギーフラッシュ $\mathrm{X}$ 線の同時照射により長スプリングの部分的な完全静止画像が得られた。X線管 を直角に配置した場合の撮影法は Fig. 6 に示す通りである。この方法と Fig. 3 (b) に示す管電圧条件で撮影した水中の泡が Fig. 7 である。異なるエネルギーでの同 時照射により画像コントラストの異なる 2 画像が得られた。

\section{5.おわりに}

デュアルフラッシュX線装置はすでに市販されているが、2 本のX線管を接続 した場合の主放電回路については発表されていないように思われる。2本のX線 管より同時にしかも同X線強度の出力を得るには、マルチニードルや本稿のフエ ライト陰極のように真空放電が安定に発生できる陰極を用いる。この装置では再 組み立て可能な管を採用したので、電極間の相対的位置関係を自由に調整するこ とができる。位置関係を同等にした場合には同フォトンエネルギー、変えた場合 には異なるエネルギーのフラッシュX線を 2 方向から同時に出力することができ る。

\section{6. 謝辞}

本研究は文部省科学研究費補助金および岩手医科大学圭陵会学術振興会研究助 成金により遂行された。 

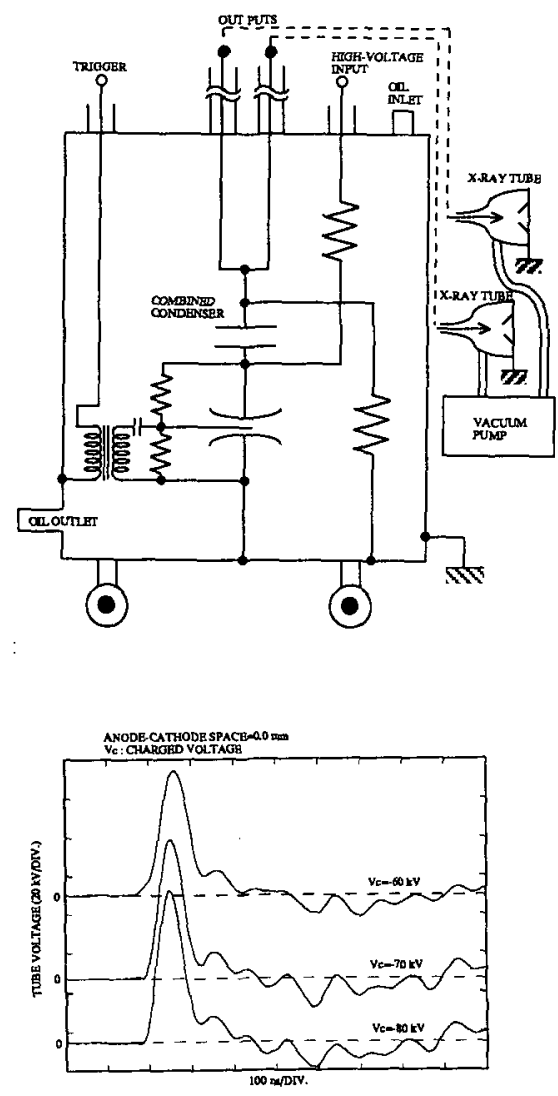

(a)
Fig. 1 Block diagram including the electric circuit of a dual-type flash $\mathrm{x}$-ray generator.

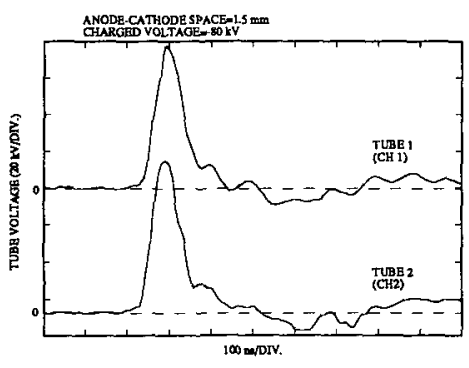

(a)

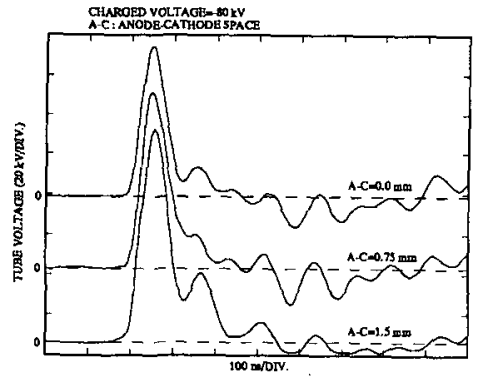

(b)

Fig. 2 Tube voltages: (a) charged voltage dependence; (b) A-C space dependence.

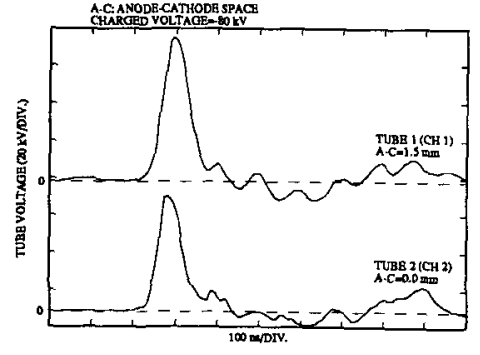

(b)

Fig. 3 Tube voltages using two flash x-ray tubes: (a) same energy; (b) dual energy. 


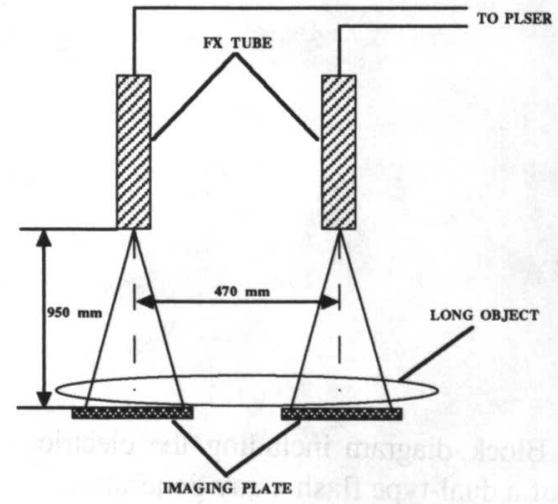

Fig. 4 Two-direction radiography for observing a long object.

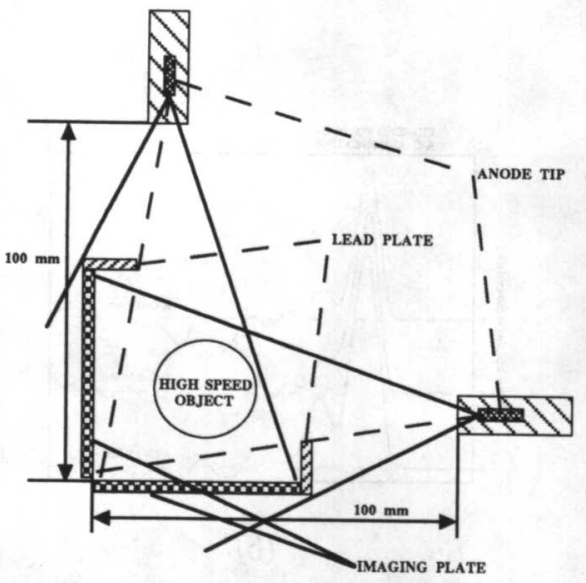

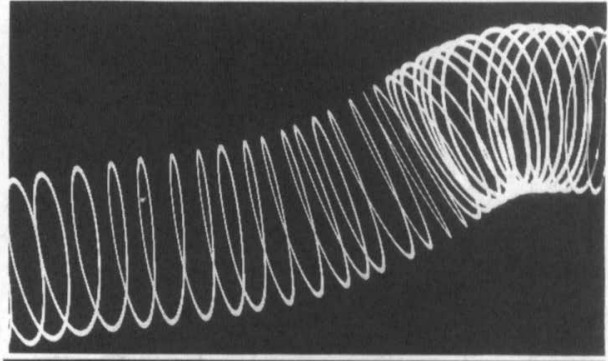

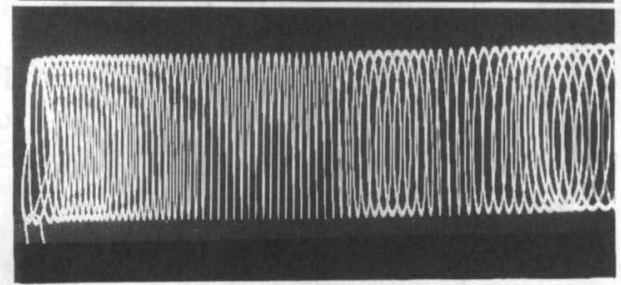

Fig. 5 Two-direction radiographs of a spring.

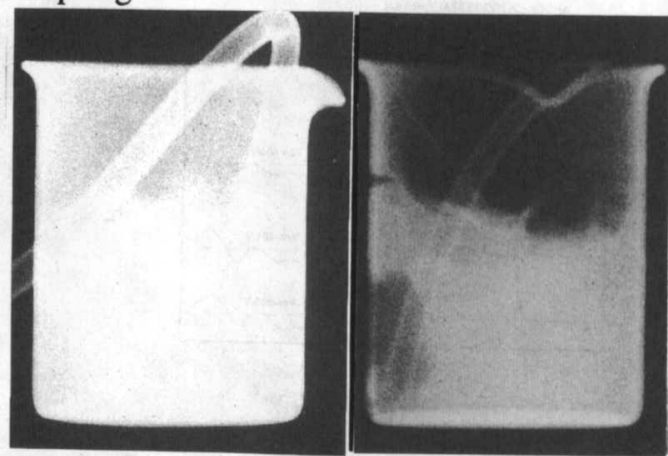

Fig. 6 Two-direction radiography (right Fig. 7 Two-direction radiographs of a angle). bubbles in water.

\section{7. 文献}

1. R. Germer, "X-ray flash techniques," J. Phys. E: Sci. Instrum., 12, pp.336-350, 1979.

2. E. Sato, K. Takahashi, M. Sagae, S. Kimura, T. Oizumi, Y. Yayasi, Y. Tamakawa and T. Yanagisawa, "Sub-kilohertz flash X-ray generator utilizing a glass-enclosed cold-cathode triode," Med. \& Biol. Eng. \& Comput., 32, pp.289-294, 1994.

3. E. Sato, M. Sagae, K. Takahashi, S.Shikoda, T. Oizumi, Y. Yayasi, Y. Tamakawa and T. Yanagisawa, "10 kHz microsecond pulsed $\mathrm{x}$-ray generator utilizing a hot-cathode triode with variable durations for biomedical radiography," Med. \& Biol. Eng. \& Comput., 32, pp.295-301, 1994.

4. K. Takahashi, E. Sato, M. Sagae, T. Oizumi, Y. Tamakawa and T. Yanagisawa, "Fundamental study on a long-duration flash x-ray generator with a surface-discharge triode," Jpn. J. Appl. Phys., 33, pp.4146-4151, 1994.

5. E. Sato, A. Shikoda, S. Kimura, M. Sagae, T. Oizumi, K. Takahashi, Y. Hayasi, T. Shoji, K. Shishido, Y. Tamakawa and T. Yanagisawa, "Repetitive compact flash x-ray generators for soft radiography," SPIE, 1801, pp.628-642, 1992. 